\title{
Dynamics and compositional changes in extracellular carbohydrates in estuarine sediments during degradation
}

\author{
Tanja Hofmann ${ }^{1}$, Astrid R. M. Hanlon ${ }^{1}$, Joe D. Taylor ${ }^{1}$, Andrew S. Ball ${ }^{1,3}$, \\ A. Mark Osborn ${ }^{1,2}$, Graham J. C. Underwood ${ }^{1, *}$ \\ ${ }^{1}$ Department of Biological Sciences, University of Essex, Wivenhoe Park, Colchester, Essex CO4 3SQ, UK \\ ${ }^{2}$ Department of Animal and Plant Sciences, University of Sheffield, Western Bank, Sheffield S10 2TN, UK \\ ${ }^{3}$ Present address: School of Biological Sciences, Flinders University of South Australia, Adelaide, GPO Box 2100, \\ Adelaide SA5100, Australia
}

\begin{abstract}
Microphytobenthic biofilms in estuarine sediments, consisting of photosynthetic microalgae, heterotrophic bacteria and their associated exopolymers, contain high concentrations of watersoluble colloidal carbohydrates that can be separated using ethanol precipitation into low molecular weight (LMW) carbohydrate and colloidal extracellular polymeric substances (cEPS). These carbohydrate-rich components are potentially a significant carbon source, but utilisation processes are not well described. Short-term (24 h) degradation studies using sediment slurries with enhanced colloidal carbohydrate and cEPS concentrations found rapid increases in LMW carbohydrate concentrations during the first $4 \mathrm{~h}$, with subsequent utilisation of LMW carbohydrate and cEPS after 8 to $24 \mathrm{~h}$. The cEPS contribution to the colloidal carbohydrate pool increased (16 to between 67 and $97 \%$ ) in control and colloidal carbohydrate-enriched slurries, with decreasing glucose and increasing mannose and xylose contents within the EPS fraction after $24 \mathrm{~h}$, suggesting initial utilisation of glucose-rich components in preference to more complex EPS. When cEPS concentrations were increased (cEPS-enrichment), there was greater EPS utilisation, and a decline in the relative contribution of EPS (72 to $31 \%$ of the colloidal carbohydrate fraction), without significant change in the monosaccharide composition in the cEPS fraction. Using selective media with cEPS as a sole carbon source, a $\beta$-proteobacterium Variovorax sp. Alr1 was isolated. Variovorax sp. Alr1 grew rapidly on cEPS as a sole carbon source, with increasing $\beta$-glucosidase activity and the production of new EPS rich in rhamnose, galactose and fucose, but showed only limited growth on EPS extracted from sediment using a hot-bicarbonate extraction procedure, despite increases in $\beta$-glucosidase and aminopeptidase activity. Differences in the short-term lability of different fractions of sediment carbohydrate and the ability of a heterotroph to utilise these fractions suggests a range of different heterotrophic bacteria may be involved in the complete degradation of EPS in situ.
\end{abstract}

KEY WORDS: Biofilms $\cdot$ EPS $\cdot$ Microphytobenthos $\cdot$ Exopolymers $\cdot$ Degradation $\cdot$ Mudflats

\section{INTRODUCTION}

Many microorganisms produce extracellular polymeric substances (EPS), consisting of polysaccharides, glycoproteins and other constituents, that form a mucilaginous matrix surrounding the microbial cell (Decho 1990). These EPS play an important role in the interaction of microorganisms and their environment, being involved in cell signalling, pathogen-host interactions, disease and creating localised microenvironments (Bhaskar \& Bhosle 2005, Bhinu 2005). In marine habitats, microalgae and cyanobacteria are major producers of EPS, forming biofilms especially in shallow water and intertidal coastal environments (Stal 
2003, Underwood \& Paterson 2003). These microphytobenthic (MPB) biofilms are sites of high rates of biogeochemical cycling, exhibiting complex rhythms of photosynthetic activity (Pinckney \& Zingmark 1991, Underwood et al. 2005), mediating nitrogen cycling processes (Risgaard-Petersen 2003, Cook et al. 2007) and contributing to the physical stability of the underlying sediment (Orvain et al. 2003, Underwood \& Paterson 2003).

The production of EPS by intertidal biofilms dominated by pennate diatoms is well described. Pennate (bilaterally symmetrical) diatoms produce EPS that predominantly consist of polysaccharides (Hoagland et al. 1993, Underwood \& Paterson 2003). The amount of photoassimilates excreted as extracellular organic carbon can exceed $70 \%$ (Smith \& Underwood 1998, Goto et al. 1999, de Brouwer \& Stal 2001, Cook et al. 2007), of which a large proportion (up to $50 \%$ ) is polymeric material (Underwood \& Paterson 2003). The quantities and chemical composition of these EPS vary with irradiance, nutrient conditions, cell growth stage and with the tidally linked rhythms of vertical migration and photosynthesis that intertidal biofilms exhibit (Higgins et al. 2003, Stal 2003, Underwood \& Paterson 2003, Chiovitti et al. 2004, Abdullahi et al. 2006, Hanlon et al. 2006). The result is a range of different EPS produced by microalgae present within sediment biofilms (Staats et al. 1999, de Brouwer \& Stal 2001, Bellinger et al. 2005), as well as a relatively chemically uncharacterised, but significant, contribution from bacteria (Mueller et al. 2006).

The combined concentration of EPS and other carbohydrate fractions can be as high as $16000 \mu \mathrm{g}$ glucose equivalents (6.4 mg C) $\mathrm{g}^{-1}$ dry wt sediment (Underwood \& Paterson 1993). Even these values $(0.64 \%$ organic carbon as carbohydrate compared to typical total organic carbon values of 1.8 to $3.0 \% \mathrm{w} / \mathrm{w}$ for intertidal mudflats, Thornton et al. 2002) may be underestimates, as the phenol sulphuric acid assay used regularly to determined sediment carbohydrates is not $100 \%$ efficient at measuring complex polysaccharides (authors' pers. obs.). Despite these high concentrations, experimental evidence suggests that there are significant fluxes of material through the different constituent pools of sediment carbohydrate. Utilisation of the low molecular weight components is rapid, within hours of production (Goto et al. 2001, Underwood 2002), while ${ }^{13} \mathrm{C}$ tracer studies have shown rapid incorporation of diatom exudates, including EPS, into bacteria and deposit-feeding metazoans within hours of labelling (Middelburg et al. 2000, Cook et al. 2007). Field studies have found evidence of coupling between algal production and bacterial extracellular enzyme activity in mudflats (van Duyl et al. 1999, 2000, Hanlon et al. 2006) and in experimental sediment slurries
(Goto et al. 2001, Haynes et al. 2007). In estuarine sediments, the dominant bacterial taxa involved in the degradation of a wide range of organic carbon compounds are members of the subphyla Flavobacteria and Sphingobacteria (previously CytophagaFlexibacter-Bacteroides) and $\alpha$ - and $\gamma$-proteobacteria (Kisand et al. 2002, Selje et al. 2005, Stevens et al. 2005). Recent molecular (DNA-based) studies have found that a small subset of the heterotrophic bacterial community within sediments respond to changes in EPS concentrations (Hanlon et al. 2006), and that enriching slurries with EPS can select for members of the $\gamma$-proteobacteria, particularly Acinetobacter sp. (Haynes et al. 2007).

The EPS pool present in estuarine sediments consists of various EPS types of different levels of biochemical complexity (predominantly polysaccharides, but also including glycoprotein and other constituent components). Because both the chemical composition and the linkage structure of EPS affect the properties of the molecule, it is possible that specific pathways of sequential degradation of these different polymers exist (Hanlon et al. 2006). During the degradation of EPS of a freshwater diatom, glucose was preferentially removed, resulting in a polymer enriched in the more refractory deoxy sugars rhamnose and fucose (Giroldo et al. 2003). The glucose content of algal EPS increases during photosynthesis and production, particularly in the EPS fractions that are more easily extracted from biofilms, while tightly bound EPS (extracted using more astringent solubilising agents, such as $0.5 \mathrm{M}$ hot-bicarbonate) consist of a more equable distribution of constituent monosaccharide groups (de Brouwer et al. 2002, Bellinger et al. 2005, Abdullahi et al. 2006, Hanlon et al. 2006). While the exact chemical structure of diatom EPS is not known, differences in composition and properties indicate that a range of different polymers are secreted into the environment (Higgins et al. 2003), and it is likely that these will be differentially susceptible to bacterial degradation. Recently, using an in situ ${ }^{13} \mathrm{C}$ pulse labeling-phospholipid fatty acid (PLFA) methodology, Bellinger et al. (2009) presented evidence that diatom EPS was incorporated into PLFA that are representative of Gram-negative bacteria within $12 \mathrm{~h}$, followed by appearance of the label in Gram-positive bacterial PLFAs after 24 to $48 \mathrm{~h}$, possibly after some microbial modification by the initial degraders. These data suggest that diatom EPS is not equally available to all microbial heterotrophs in sediments, and that consortia of specialists may exist.

In this paper we present data from 2 experiments. Expt 1 investigated changes in carbohydrate content and monosaccharide composition over $24 \mathrm{~h}$ in sediment slurries enriched with different components of 
extracellular carbohydrates - low molecular weight (LMW) carbohydrate and colloidal EPS (cEPS) - extracted from intertidal diatom biofilms. We tested the hypothesis that the sediment bacterial community will differentially degrade the added carbohydrate material derived from extracts of diatom-dominated MPB biofilms. In Expt 2, we isolated an EPS-degrading bacterium from a sediment supporting MPB biofilms, and investigated the ability of this isolate to grow on and degrade 2 different biofilm EPS fractions: (1) cEPS, present in aqueous extractions of biofilms, and (2) a more complex and refractory carbohydrate fraction obtained using a hot-bicarbonate extraction procedure (Bellinger et al. 2005).

\section{MATERIALS AND METHODS}

Field sampling. All samples and material for carbohydrate extraction were collected from MPB biofilms on an intertidal mudflat in Alresford Creek, Colne Estuary, UK (51 $\left.50.2^{\prime} \mathrm{N}, 0^{\circ} 59.5^{\prime} \mathrm{E}\right)$. Alresford Creek is a typical mid-estuary intertidal site (salinity ranges from 18 to $30 \%$ ), with fine cohesive mudflats supporting abundant biofilms consisting predominantly of diatoms (Underwood et al. 2005, Hanlon et al. 2006). The nutrient characteristics and distribution of microphytobenthos in the Colne are given in Thornton et al. (2002), Bellinger et al. (2005) and Thornton et al. (2007). Sediments were sampled at low tide using plastic cores, (internal diameter $=6.5 \mathrm{~cm}$, length $=10 \mathrm{~cm}$ ). Cores containing sediment were transported back to the laboratory within $1 \mathrm{~h}$, the surface $2 \mathrm{~mm}$ of sediment removed and samples for carbohydrate extraction immediately frozen at $-80^{\circ} \mathrm{C}$ for $1 \mathrm{~h}$, followed by lyophilisation overnight. Expt 1 was carried out during May 2003, with the sediments for the enrichments being sampled 1 wk before the collection of fresh sediments used as the inoculum for the slurries. Expt 2 took place during September 2005. The material for isolating the bacteria and the subsequent liquid cultures were collected on the same day.

Extraction of carbohydrate fractions for isolation and microcosm experiments. Three different operational carbohydrate fractions were extracted from freeze-dried sediments (see Underwood \& Paterson 2003). The colloidal fraction contains all dissolved and colloidal carbohydrate material, including LMW material and larger polysaccharides. EPS carbohydrate is defined as material precipitating in alcohol (Decho 1990) and 2 fractions were obtained: EPS present within the colloidal extract (cEPS) and EPS extracted using a $0.5 \mathrm{M} \mathrm{NaHCO}_{3}$ solution at $95^{\circ} \mathrm{C}$ (HB-EPS). Carbohydrate fractions were extracted by weighing $4 \mathrm{~g}$ of freeze-dried sediment into each of 50 centrifuge tubes
$(50 \mathrm{ml})$ and adding $20 \mathrm{ml}$ saline $(25 \% \mathrm{NaCl}$ in distilled water, $\mathrm{dH}_{2} \mathrm{O}$ ). Tubes were mixed by vortexing, incubated for $30 \mathrm{~min}$ at $25^{\circ} \mathrm{C}$ and then centrifuged at room temperature $(3000 \times g, 15 \mathrm{~min})$ to produce a supernatant containing colloidal material, including carbohydrates (colloidal-S, Underwood et al. 1995). Aliquots of this colloidal material were frozen for use in the experiments. To obtain cEPS, $10 \mathrm{ml}$ of the fresh supernatant from each tube was transferred into a new centrifuge tube containing $30 \mathrm{ml}$ of ethanol (75\% v/v final concentration) and left at $4{ }^{\circ} \mathrm{C}$ for $24 \mathrm{~h}$ in order to precipitate the EPS fraction. Tubes were then centrifuged at room temperature $(3000 \times g, 15 \mathrm{~min})$, the supernatant was discarded and the resultant cEPS pellets pooled, resuspended in $50 \mathrm{ml} \mathrm{dH}_{2} \mathrm{O}$ and filter-sterilised $(0.2 \mu \mathrm{m})$.

To obtain hot-bicarbonate extractable EPS (cf. Bellinger et al. 2005), the sediment pellets remaining after the extraction of readily solubilised colloidal material were retained and all supernatant discarded. The sediment pellets were subjected to 2 sequential extractions. First, a hot water extraction (HW) $\left(95^{\circ} \mathrm{C}\right.$ for $1 \mathrm{~h}$ ) was used to remove intracellular components and other EPS components. The HW supernatant, which extracts the majority of the intracellular storage carbohydrate (glucan) of diatoms, as well as solubilising some of the more refractory EPS in the sediments (Bellinger et al. 2005), was discarded. Then the sediment pellet was subjected to a hot-bicarbonate (HB) extraction $\left(0.5 \mathrm{M} \mathrm{NaHCO}_{3}, 95^{\circ} \mathrm{C}\right.$ for $\left.1 \mathrm{~h}\right)$, following the methods of Bellinger et al. (2005). The supernatant following $\mathrm{HB}$ extraction was precipitated in ethanol as above (10 $\mathrm{ml}$ in $30 \mathrm{ml}$ ethanol), the EPS pellets pooled,

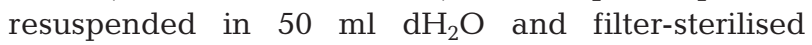
$(0.2 \mu \mathrm{m})$. This was designated the HB-EPS fraction. The extracted and dissolved exopolymers in the cEPS and HB-EPS extractions were then re-precipitated in $75 \%$ ethanol for a second time in order to remove salt and excess $\mathrm{NaHCO}_{3}$. The final cEPS and HB-EPS pellets were frozen, and subsamples used for amendment of sediment slurry experiments and for the isolation of EPS degrading bacteria.

Determination of carbohydrate concentrations in extracts. Concentrations of colloidal carbohydrate, cEPS and HB-EPS were measured using the phenolsulphuric acid assay (Dubois et al. 1956, Hanlon et al. 2006). In brief, $0.5 \mathrm{ml}$ of $5 \%$ phenol and $2.5 \mathrm{ml}$ of concentrated $\mathrm{H}_{2} \mathrm{SO}_{4}$ were added to a $1 \mathrm{ml}$ sample of material (either colloidal extract or an EPS pellet resuspended after precipitation) and left to cool at room temperature for $30 \mathrm{~min} . \mathrm{H}_{2} \mathrm{O}$ blanks were treated in the same way. Absorbance was subsequently measured at $485 \mathrm{~nm}$ and carbohydrate concentration quantified $\left(\mu \mathrm{g} \mathrm{ml}^{-1}\right)$ as glucose equivalents using a glucose standard. 
The concentration of LMW carbohydrates within colloidal fractions, defined as the carbohydrate material that does not precipitate in $75 \%$ alcohol, was calculated by the difference between colloidal and cEPS concentrations of individual samples.

Expt 1. Changes in colloidal carbohydrate and cEPS concentrations in sediment slurries over 24 h: To determine the short-term changes in the concentrations and monosaccharide composition of colloidal carbohydrate and cEPS fractions in sediment slurries, 4 slurry treatments were established, consisting of sets of triplicate $500 \mathrm{ml}$ conical flasks, each containing $20 \mathrm{~g}$ wet wt of fresh surface sediment (top $2 \mathrm{~mm}$ ) from Alresford Creek. The first treatment consisted of unamended control slurries; these were made up to $250 \mathrm{ml}$ with minimal seawater medium (M9 MM) (no added organic carbon source, Miller 1972) with a final salinity of $25 \%$. Slurries in the second treatment, colloidal carbohydrate enrichments, were made by the addition of previously extracted colloidal carbohydrate, to give a final enrichment of $+133 \%$ colloidal carbohydrate and $+780 \%$ cEPS (Table 1). The volume was made up to $250 \mathrm{ml}$ with M9 MM, with salinity adjusted to $25 \%$. The third treatment consisted of poisoned controls of the colloidal carbohydrate enrichments, and was established using an identical setup but with the addition of $\mathrm{HgCl}_{2}$ at $2 \%$ final concentration (w/v) to prevent biological activity. The fourth treatment consisted of previously extracted cEPS, redissolved in $25 \% \mathrm{NaCl}$ saline and added to another three $500 \mathrm{ml}$ flasks (cEPS enrichments), giving a final EPS enrichment of $+2289 \%$ (and also an increase in colloidal concentration of $+312 \%$ ) compared to the control slurries (Table 1).

Flasks were gently shaken $(30 \mathrm{rpm})$ on a rotating incubator and maintained at $15^{\circ} \mathrm{C}$ in the dark. After 2, 4, 8 and $24 \mathrm{~h}$, a $35 \mathrm{ml}$ subsample was removed from each flask. Five $\mathrm{ml}$ of each subsample was used to determine colloidal and cEPS concentrations, and the remaining slurry material was used to determine the monosaccharide composition of the cEPS component (see below). Monosaccharide composition was only determined at 0,4 and $24 \mathrm{~h}$ in the poisoned treatment.
Expt 2. Isolation of EPS-degrading bacteria: One gram of fresh surface sediment (top $2 \mathrm{~mm}$ ) from Alresford Creek was added to $9 \mathrm{ml}$ of extraction buffer (50 mM Tris-HCl buffer, $\mathrm{pH}$ 7.5), vortex mixed and sonicated using three 1 min cycles with 1 min cooling on ice between each cycle (Osborn et al. 1993). The inoculum was then filtered through a $0.4 \mu \mathrm{m}$ filter to exclude protists and serially diluted $\left(10^{-2}\right.$ to $\left.10^{-7}\right)$ in M9 MM. Microtitre plates were set up with varying concentrations of both bacterial inoculum $\left(10^{-2}\right.$ to $\left.10^{-7}\right)$ and cEPS extract ( 1 to $200 \mu \mathrm{g}$ glucose equivalents $\mathrm{ml}^{-1}$ ) made up to $200 \mu \mathrm{l}$ with M9 MM in each of 96 wells in order to isolate EPS-degrading bacteria. Control wells contained either no inoculum or no cEPS extract. Plates were incubated at $25^{\circ} \mathrm{C}$ in the dark. Growth was detected by daily measuring absorbance using a microplate reader at $750 \mathrm{~nm}$. If growth was detected in a well, $10 \mu \mathrm{l}$ of inoculum was transferred into a well on a fresh microtitre plate, maintaining the equivalent concentrations of EPS extract and growth conditions. If growth continued in the new plates after $5 \mathrm{~d}, 100 \mu \mathrm{l}$ of inoculum was then transferred into $5 \mathrm{ml}$ of culture medium (M9 MM and EPS at original growth concentration) grown again prior to subculture onto solid medium (M9 MM agar containing EPS). Single colonies were picked and repeatedly streaked for purity. A number of pale white/yellow colonies were isolated, and single colonies were subcultured in M9 MM plus EPS. Four pure cultures were obtained by this process. Harvested cell pellets were used as crude template (Osborn et al. 1993) for PCR amplification of 16S rRNA genes using primers $27 \mathrm{~F}$ and $1492 \mathrm{R}$, prior to generation of a partial 16S rRNA 5' end sequence with subsequent (FAST-ALL (FASTA) comparison to sequences in the European Molecular Biological Laboratory (EMBL) database using standard approaches (see Haynes et al. 2007). One isolate chosen as the focus for the further experiments described below was presumptively identified as belonging to the genus Variovorax $(99.8 \%$ identity to Variovorax sp. D10, accession number DQ268787), a member of the $\beta$-proteobacteria. The 16S rRNA gene sequence of this

Table 1. Initial conditions for slurries in Expt 1 (with sediment) and Expt 2 (with single species inoculum). Enrichment factors (\% relative to control sediment slurries) for Expt 1 are given. cEPS: colloidal extracellular polymeric substances; HB-EPS: see 'Materials and methods'

\begin{tabular}{|c|c|c|c|c|c|c|c|}
\hline \multirow{2}{*}{ Expt } & \multirow{2}{*}{ Treatment } & \multicolumn{3}{|c|}{ Carbohydrate conc. ( $\mu$ g gluc. equiv. $\mathrm{ml}^{-1}$ slurry) } & \multicolumn{2}{|c|}{- Volume $(\mathrm{ml})$} & \multirow[t]{2}{*}{$\mathrm{n}$} \\
\hline & & Total & Colloidal (enrich) & cEPS (enrich) & Experimental & Sampled & \\
\hline \multirow[t]{3}{*}{1} & Control & & 9.3 & 1.2 & 250 & 35 & $3^{a}$ \\
\hline & Colloidal & & $21.7(+133 \%)$ & $10.2(+780 \%)$ & 250 & 35 & $3^{a}$ \\
\hline & cEPS & & $38.4(+312 \%)$ & $27.7(+2289 \%)$ & 250 & 35 & $3^{\mathrm{a}}$ \\
\hline \multirow[t]{2}{*}{2} & cEPS & 10.2 & 2.0 & 3.1 & 50 & 50 & 3 \\
\hline & HB-EPS & 14.7 & 7.8 & 5.3 & 50 & 50 & 3 \\
\hline
\end{tabular}


isolate (Variovorax sp. Alr1) has been deposited in the EMBL database under accession number FM179680.

Growth and degradation on CEPS and HB-EPS by the Variovorax sp. isolate: The enrichment culture experiments consisted of 32 autoclaved $50 \mathrm{ml}$ conical flasks, 16 of which contained M9 MM enriched with cEPS extract (46.7 ml M9 MM and $1.3 \mathrm{ml}$ cEPS), while the other 16 flasks were enriched with HB-EPS (41.75 ml M9 and 6.25 ml HB-EPS) (final concentrations given in Table 1). All flasks were inoculated with a $2 \mathrm{ml}$ inoculum of Variovorax sp. culture, resulting in initial bacterial numbers of $8.9 \times 10^{6}$ cells ml ${ }^{-1}$ slurry.

The microcosms were incubated aerobically in the dark at $25^{\circ} \mathrm{C}$, at $130 \mathrm{rpm}$ for $72 \mathrm{~h}$. One flask of each enrichment was sampled immediately $(0 \mathrm{~h})$; subsequently, 3 flasks of each enrichment were randomly selected at 12, 24, 48 and $72 \mathrm{~h}$ for analysis of carbohydrate concentrations ( $8 \mathrm{ml}$ removed for total carbohydrates, colloidal and EPS fractions), $\beta$-glucosidase and aminopeptidase activity (1 $\mathrm{ml}$ each), bacterial cell numbers $(2 \mathrm{ml})$, and changes in monosaccharide composition of cEPS and HB carbohydrate fractions (37 ml).

Carbohydrate concentration: The concentration of total carbohydrates in $1 \mathrm{ml}$ of subsample was determined immediately as glucose equivalents using the phenol-sulphuric acid method (as above). The remaining $7 \mathrm{ml}$ subsample was filtered through a $0.2 \mu \mathrm{m}$ filter in order to remove bacteria. The concentration of colloidal carbohydrates was then measured using $1 \mathrm{ml}$ of the filtrate as above. Five $\mathrm{ml}$ of the filtrate were added to $13.5 \mathrm{ml}$ ethanol, precipitating the EPS fraction overnight as above, and then used to determine EPS concentration using the phenol-sulphuric acid method.

$\beta$-glucosidase and aminopeptidase activity: Maximum potential rates of extracellular $\beta$-glucosidase and aminopeptidase activity were determined using fluorescently labelled substrates (Hoppe 1983). Subsamples of $1 \mathrm{ml}$ were added to centrifuge tubes containing $0.5 \mathrm{ml}$ of sodium azide $\left(0.2 \%\right.$ final concentration $\left.\mathrm{NaN}_{3}\right)$ and $8 \mathrm{ml}$ of either MUF- $\beta$-D-glucopyranoside solution (Sigma-Aldrich, $320 \mu \mathrm{g} \mathrm{ml} \mathrm{m}^{-1}$ in $70 \%$ ethanol) or L-Leucine-7-amino-4-methylcoumarin hydrochloride (Sigma-Aldrich, $320 \mu \mathrm{g} \mathrm{ml}^{-1}$ ) respectively, at final saturating substrate concentrations of $1 \mathrm{mM}$ (Hoppe 1983). The metabolic inhibitor sodium azide was added to the slurries to prevent de novo production of extracellular $\beta$-glucosidases or aminopeptidase.

Reaction tubes were incubated at $20^{\circ} \mathrm{C}$ for $4 \mathrm{~h}$. Subsamples of $2.5 \mathrm{ml}$ were taken at 0,2 and $4 \mathrm{~h}$ and centrifuged at room temperature $(3000 \times g, 15 \mathrm{~min})$. The supernatant was transferred into cuvettes containing $0.2 \mathrm{ml}$ of Tris-borate EDTA buffer ( $\mathrm{pH} 10)$ and fluorescence was measured (Luminescence Spectophoto- meter LS50, Perkin-Elmer) with excitation at $365 \mathrm{~nm}$ and measuring emission at $445 \mathrm{~nm}$ ( $\beta$-glucosidase) and $450 \mathrm{~nm}$ (aminopeptidase). 4-Methylumbelliferone (MUF) and 7-amino-4-methylcoumarin (AMC) were used as standards, and enzyme activity rates were calculated based on MUF or AMC release from the linear part of the time-dependent activity curves.

Bacterial cell numbers: Bacterial cell numbers were determined using acridine orange counts. A 2 ml subsample was fixed in gluteraldehyde (final concentration $0.5 \% \mathrm{w} / \mathrm{v})$. One hundred $\mu \mathrm{l}$ of acridine orange $(0.5 \% \mathrm{w} / \mathrm{v})$ was added and the sample incubated in the dark for $3 \mathrm{~min}$. The sample was then filtered through a black $0.2 \mu \mathrm{m}$ membrane filter (Millipore) under low pressure and rinsed with $5 \mathrm{ml}$ of $0.2 \mu \mathrm{m}$ filter-sterilised deionised water. The filter paper was placed on a microscope slide on top of a drop of immersion oil. A further drop of oil was placed on top of the filter paper before a cover slip was added. Bacteria were counted in 10 fields of view in all squares of a $10 \times 10$ eye piece grid using UV illumination and $\times 1000$ oil immersion.

Monosaccharide composition: The monosaccharide content of cEPS was determined using methods described by Wustman et al. (1997) and Bellinger et al. (2005). cEPS were extracted from slurries or experimental cultures as described above. Pellets of cEPS (after ethanol precipitation) were redissolved in distilled water and dialyzed using a 10-12 kDa molecular weight cut off (MWCO) filter against $\mathrm{dH}_{2} \mathrm{O}$ for $24 \mathrm{~h}$ (water changes at 2, 4 and $24 \mathrm{~h}$ ). Desalted EPS was freeze-dried for analysis.

Monosaccharide profiles were determined in triplicate (when applicable) for each fraction following the methods described in Wustman et al. (1997). Briefly, 1 to $5 \mathrm{mg}$ of freeze-dried EPS material was hydrolyzed in $2 \mathrm{M}$ trifluoroacetic acid at $121^{\circ} \mathrm{C}$ for $3 \mathrm{~h}$, followed by reduction to alditol acetates for identification and quantitation by gas chromatography-mass spectroscopy (Finnigan-MAT Magnum Ion Trap). Identification and quantification were based on response factors relative to standards subjected to the same hydrolytic procedure (Bellinger et al. 2005). Monosaccharide distributions are expressed as the relative abundance of individual monosaccharides within the total analyzed fraction.

Statistical analysis. Data were checked for normality using a Kolmogorov-Smirnov test, and transformed using $\log (n+1)$ where necessary. For Expt 1, a repeated-measures ANOVA was used to determine significant changes in concentrations of different carbohydrate fractions with time. In Expt 2, each replicate was independent, and 1-way ANOVA was used to determine significant changes in carbohydrate concentrations or enzyme activities with time followed by post hoc Tukey's tests. Minitab v.13.1 was used. 


\section{RESULTS}

\section{Expt 1}

In the control (unamended) slurries, the majority of the colloidal carbohydrate consisted of LMW compounds (cEPS was $16 \%$ of the colloidal fraction) for the first $4 \mathrm{~h}$. Colloidal concentrations increased slightly, caused by an increase in LMW carbohydrates, before a rapid decline in the concentrations of low molecular weight carbohydrates $\left(F_{4,2,14}=7.49\right.$, p < 0.01) by $8 \mathrm{~h}$. However, colloidal concentrations did not significantly change, due to a significant increase in the concentrations of cEPS after $8 \mathrm{~h}\left(F_{4,2,14}=3.83, \mathrm{p}<0.05\right)$ (Fig. $\left.1 \mathrm{a}\right)$. By $8 \mathrm{~h}, 93 \%$ of the colloidal carbohydrate extracted was polymeric (i.e. cEPS); by $24 \mathrm{~h}$ the cEPS component reached $97 \%$. Over a $24 \mathrm{~h}$ period, the LMW carbohydrates present at the beginning of the experiment were rapidly consumed, with an increase in the concentrations of cEPS. The cEPS produced within the slurry was different from the initial cEPS in terms of its monosaccharide composition, with a major reduction in the proportion of glucose present in the polymers, and substantial increases in both relative abundance and concentrations (EPS concentration increased by an order of magnitude) of galactose, mannose and xylose in the cEPS present after 8 and $24 \mathrm{~h}$ (Fig. 2a).

Slurries enriched with colloidal carbohydrate (containing both LMW and cEPS material) had a higher proportion of EPS ( $46 \%$ ) at time 0 than the control slurries. During the first $4 \mathrm{~h}$, there was a 2 -fold increase in colloidal carbohydrate concentrations $\left(F_{4,2,14}=8.31\right.$, $\mathrm{p}<0.01)$, caused primarily by increases in nonpolymeric (i.e. LMW) components (cEPS declined to $33 \%$ of the colloidal fraction) (Fig. 1b). After 8 h, these high concentrations of LMW material declined signifi-
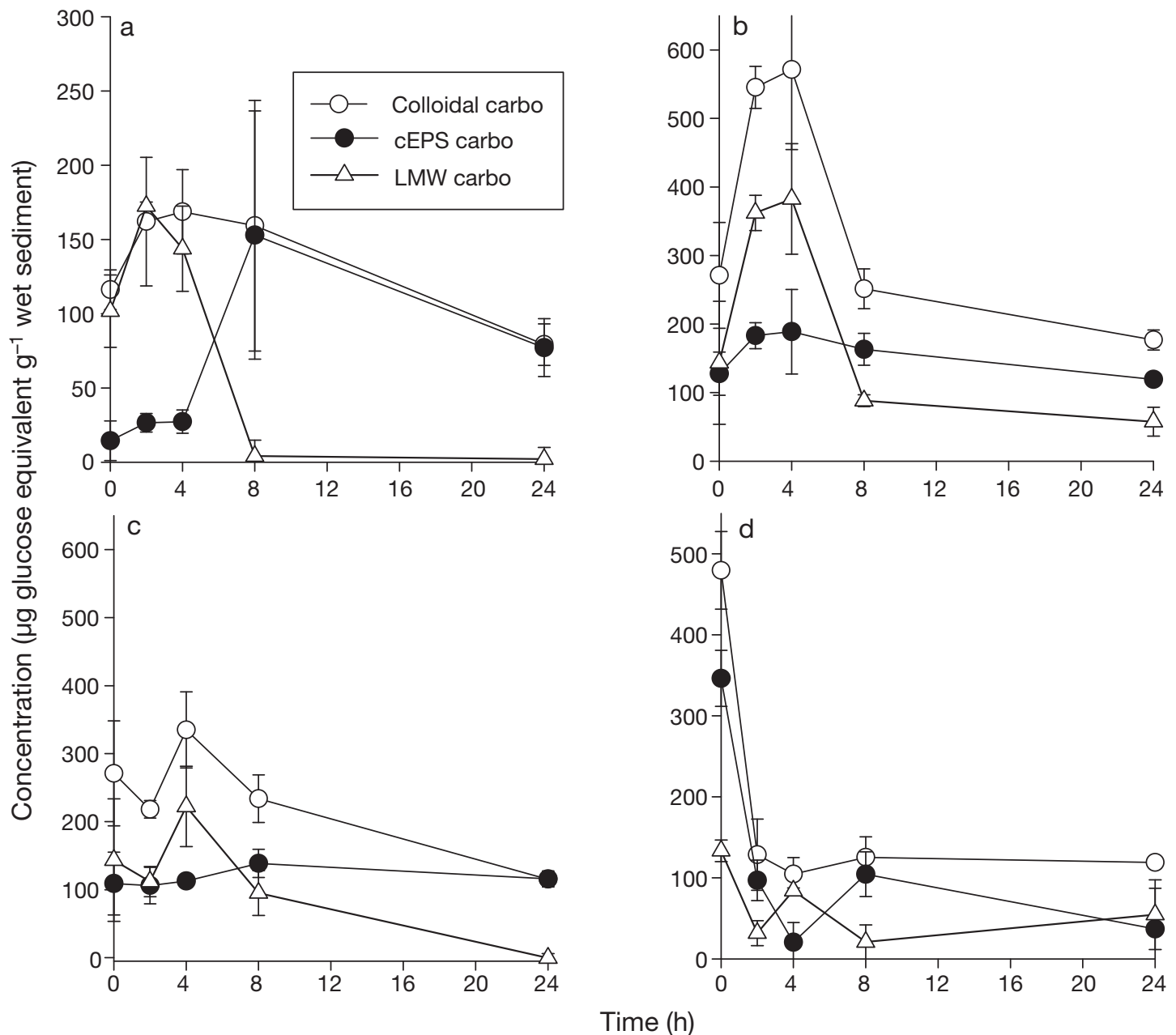

Fig. 1. Changes in concentrations of colloidal carbohydrate, colloidal extracellular polymeric substances (cEPS) and low molecular weight (LMW) carbohydrate in slurries of estuarine sediment (top $2 \mathrm{~mm}$ ) over $24 \mathrm{~h}$. (a) Unamended controls, (b) enriched with colloidal carbohydrate, (c) enriched with colloidal carbohydrate but poisoned with $2 \% \mathrm{HgCl}_{2}$, and (d) enriched with cEPS. Values are means $\pm \mathrm{SE}$ (glucose equivalent per gram wet sediment), $\mathrm{n}=3$. Carbo: carbohydrate 
a

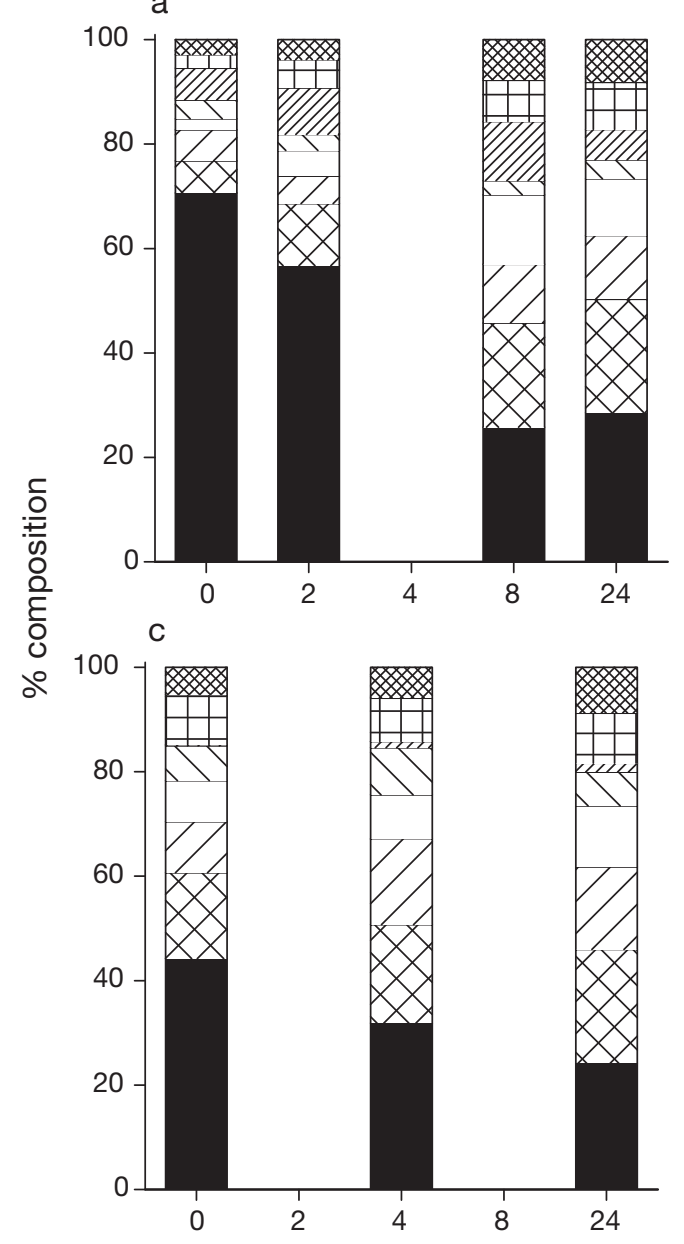

b
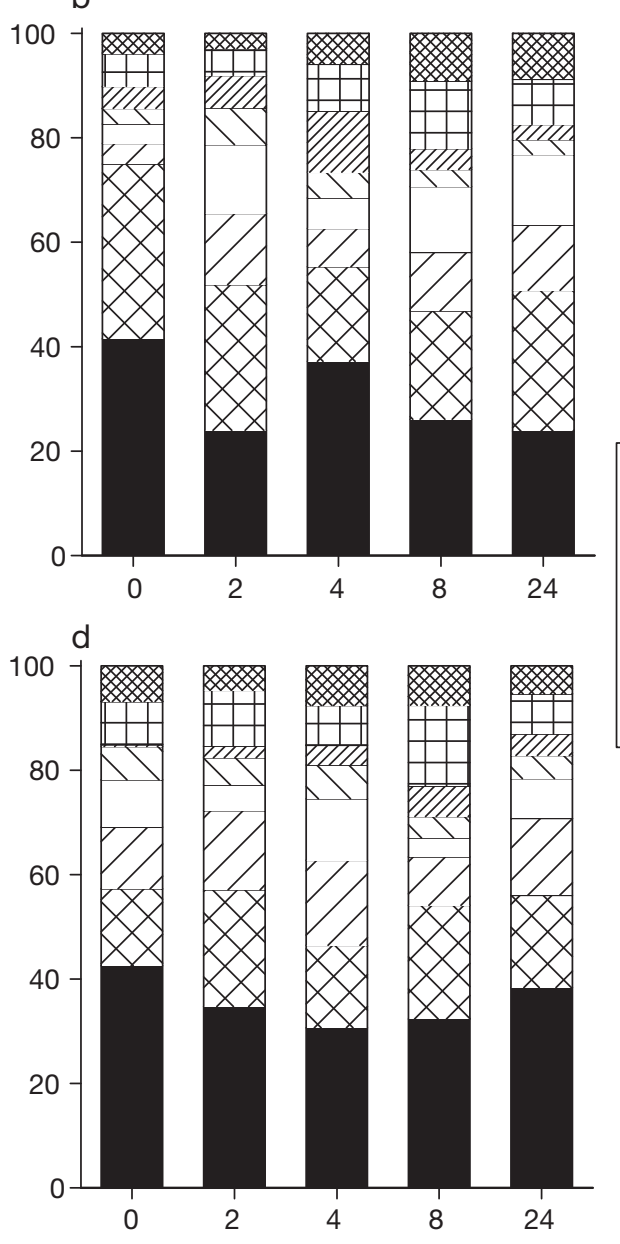

Rhamnose

$\square \square$ Fucose IIIZ Ribose $\square \triangleright$ Arabinose $\square$ Xylose $\square$ Mannose $\square \nabla$ Galactose Glucose

Time (h)

Fig. 2. Monosaccharide composition (\% relative abundance) of cEPS extracted from slurries of estuarine sediment (top 2 mm) over 24 h. (a) Unamended controls, (b) enriched with colloidal carbohydrate, (c) enriched with colloidal carbohydrate but poisoned with $2 \% \mathrm{HgCl}_{2}$, and (d) enriched with cEPS. Mean data of 3 triplicate measures of pooled samples. Control sample at $4 \mathrm{~h}$ was lost. Monosaccharides were only measured at 0,4 and $24 \mathrm{~h}$ in (c)

cantly, and were below starting concentrations by $24 \mathrm{~h}$ $\left(F_{4,2,14}=6.9, \mathrm{p}<0.01\right)$. EPS concentrations showed no significant changes overall (after a slight rise at $2 \mathrm{~h}$ ) over the $24 \mathrm{~h}$ period; however, the contribution of cEPS to the colloidal fraction increased to $67 \%$ by $24 \mathrm{~h}$ (Fig. 1b). The monosaccharide composition of cEPS was different from the composition of EPS in the controls, with less glucose and a greater proportion of galactose in the polymers (Fig. 2b). Over the $24 \mathrm{~h}$ period, despite no significant change in EPS concentration, there was a decrease in the abundance of glucose and galactose, with increasing proportions of mannose and xylose in the cEPS fraction. After $8 \mathrm{~h}$, there were no significant differences in the cEPS monosaccharide composition between the controls and the colloidal-enriched slurries (Figs. 2a,b). The poisoned colloidal enrichments showed no significant change in cEPS concentration over $24 \mathrm{~h}$ (Fig. 1c), although there was a decrease in the proportion of glucose by $24 \mathrm{~h}$ (Fig. 2c). There was some increase in the concentration of LMW carbohydrate material by $4 \mathrm{~h}$, but this was not present after $24 \mathrm{~h}$ (Fig. 1c). These changes were relatively minor compared to those occurring in the non-poisoned colloidal enrichment (Fig. 1b).

EPS enrichment resulted in high initial concentrations of colloidal carbohydrate $(480 \mu \mathrm{g}$ glucose equivalents $\left.\mathrm{g}^{-1}\right)$, consisting of a high proportion of cEPS $(72 \%)$. Concentrations of colloidal carbohydrate and cEPS decreased significantly (>70\%) over the first $4 \mathrm{~h}$ of the experiment $\left(F_{4,2,14}=21.4\right.$ and 60.5 respectively, $\mathrm{p}<0.001$ ) (Fig 1d). cEPS concentrations then rose: at $8 \mathrm{~h}$ cEPS made up $83 \%$ of the colloidal fraction, then declined to $31 \%$ by 24 h (Fig. 1d). LMW carbohydrate 
concentrations also decreased significantly in the first $2 \mathrm{~h}$ of the experiment $\left(F_{4,2,14}=5.46, \mathrm{p}<0.05\right)$, but concentrations then significantly rose after $4 \mathrm{~h}$ and fell at $8 \mathrm{~h}$. The initial cEPS composition differed from that of the controls and colloidal enrichments, with less glucose and greater amounts of rhamnose and xylose (Fig. 2d), but did not significantly alter in composition, despite large changes in concentration, over the $24 \mathrm{~h}$ period.

\section{Expt 2}

Variovorax sp. Arl1 grew rapidly in the cEPS-enriched cultures. Cells exhibited logarithmic growth (mean $\pm \mathrm{SE}$ intrinsic rate of growth $=0.55 \pm 0.06 \mu \mathrm{d}^{-1}, \mathrm{n}=10$ ) and population densities increased from $8.9 \times 10^{6}$ to $13.3 \times 10^{9}$ $\mathrm{ml}^{-1}$ over $72 \mathrm{~h}$. Correlated with increases in cell numbers were concentrations of total carbohydrates, which increased logarithmically over the $72 \mathrm{~h}\left(F_{4,14}=169.3, \mathrm{p}<\right.$ 0.001) (Fig. 3a). Concentrations of colloidal carbohydrate also increased $\left(F_{4,14}=34.3, \mathrm{p}<0.001\right)$, caused by increases in CEPS $\left(F_{4,14}=5.06, \mathrm{p}<0.05\right)$ in the cultures, mirrored by non-significant increases in LMW carbohydrates. From 12 to $72 \mathrm{~h}$, between 50 and $70 \%$ of the colloidal fraction consisted of cEPS (Fig. 3a). There was a significant decrease in the relative abundance of glucose in the cEPS fraction of these cultures, with increasing amounts of galactose and the appearance of rhamnose in the EPS after 24 h. (Fig. 4).

$\beta$-glucosidase activity decreased in the first $12 \mathrm{~h}$, but then significantly increased throughout the course of the experiment $\left(F_{4,14}=159.1, \mathrm{p}<0.001\right)$ (Fig. 3b). Aminopeptidase activity increased slightly between 12 and $48 \mathrm{~h}$ before declining. Given the large increases in cell density over this period, the relatively stable
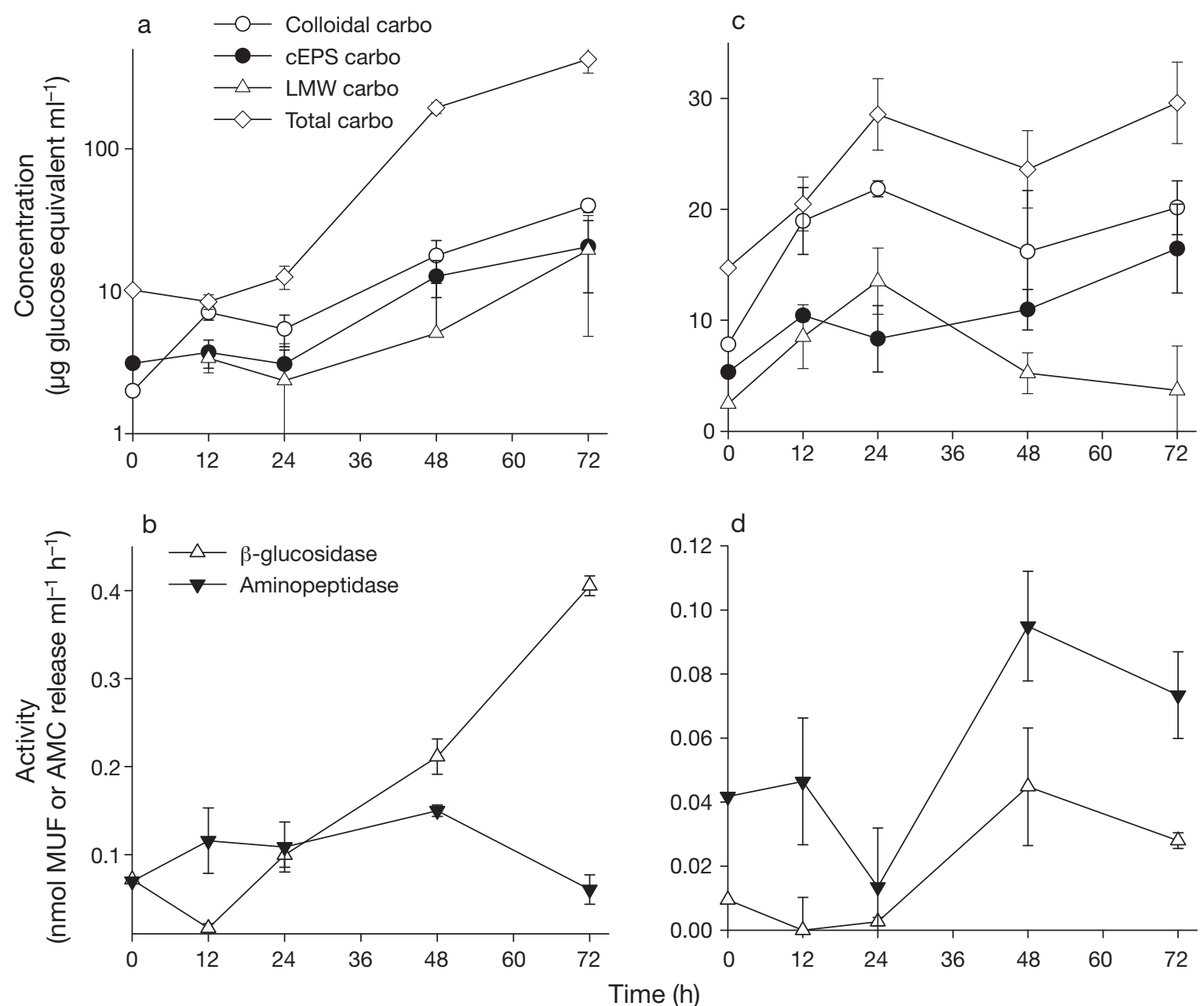

Fig. 3. Changes in $(\mathrm{a}, \mathrm{c})$ concentrations of total, colloidal, cEPS and low molecular weight (LMW) carbohydrates and (b,d) $\beta$-glucosidase (MUF) and aminopeptidase (AMC) activity in cultures of Variovorax sp. over 72 h, cultured in M9 MM and amended with $(\mathrm{a}, \mathrm{b})$ cEPS or $(\mathrm{c}, \mathrm{d})$ hot-bicarbonate extracted EPS from diatom-dominated biofilms as a carbon source. Values are means $\pm \mathrm{SE}, \mathrm{n}=3$. Carbo: carbohydrate 


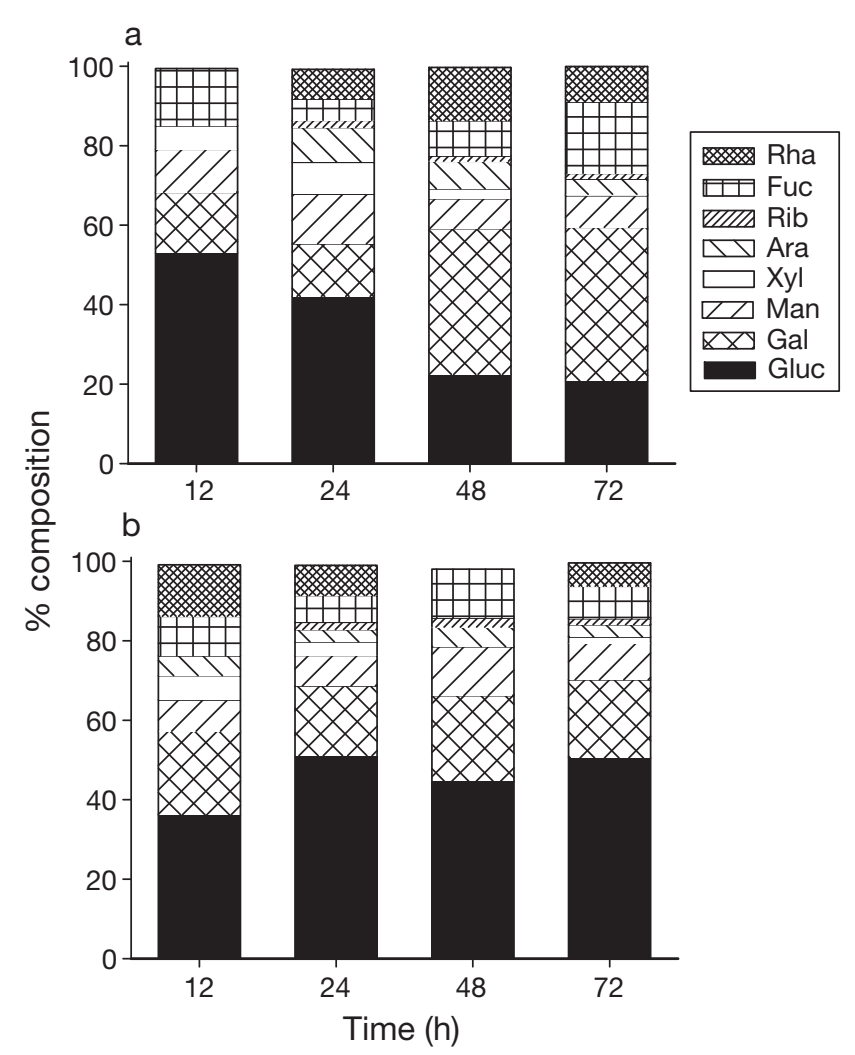

Fig. 4. Monosaccharide composition (\% relative abundance) of cEPS extracted from Variovorax sp. cultures grown in M9 MM amended with (a) cEPS or (b) hot-bicarbonate extracted EPS from diatom-dominated biofilms. Mean data of 3 triplicate measures of pooled samples. Abbreviations: see Fig. 2

level of aminopeptidase activity in the slurries indicated a decrease in cell-specific aminopeptidase activity towards the end of the experiment.

There was no net increase in Variovorax sp. cell density in the cultures with HB-EPS as a carbon source, and the intrinsic growth rate was not significantly different from zero (mean $\pm \mathrm{SE}$ intrinsic rate of growth $=$ $-0.01 \pm 0.02 \mu \mathrm{d}^{-1}, \mathrm{n}=10$ ). There was a small, but significant, increase in total carbohydrate concentration $\left(F_{4,14}=4.44, \mathrm{p}<0.05\right)$ in these cultures over $72 \mathrm{~h}$, a small increase in colloidal carbohydrate $\left(F_{4,14}=3.32\right.$, $\mathrm{p}=0.056)$ and upward trends in cEPS concentrations (Fig. 3c), but compared to the cEPS-treatments, little evidence of growth and extracellular carbohydrate production. There was a slight increase in the relative abundance of glucose in the cEPS fraction after $24 \mathrm{~h}$, but otherwise, the monosaccharide composition of the cEPS in the hot-bicarbonate treatment did not significantly change over $72 \mathrm{~h}$ (Fig. 4). Though there was no net growth in bacteria, there were significant increases in $\beta$-glucosidase activity $\left(F_{4,14}=3.73, \mathrm{p}<0.05\right)$ and in aminopeptidase activity $\left(F_{4,14}=3.51, \mathrm{p}<0.05\right)$, particularly after 48 h (Fig. 3d).

\section{DISCUSSION}

Carbohydrates can only be utilised once bacteria have transported the molecules across their cell wall and cell membrane. While this is possible for monosaccharides and small oligosaccharides, larger polysaccharides generally cannot be utilised until they have been cleaved by extracellular enzymes (Priest 1992, Vetter et al. 1998), or after abiotic cleavage of polymer chains by hydrolysis or photolysis. A conceptual model of carbohydrate utilisation in sediments involves the progressive disassembly of the complex carbohydrates present in the sediment from detrital inputs, or produced in situ by microphytobenthos or by bacteria and other microorganisms, into increasingly 'available' fractions by the actions of biotic and abiotic processes (Fig. 5).

\section{Utilisation of low molecular weight carbohydrate}

All 3 treatments in Expt 1 showed major losses of LMW carbohydrates within the first $8 \mathrm{~h}$, as bacteria rapidly utilised the LMW component of colloidal carbohydrates present within sediment slurries. A significant proportion of the photoassimilated carbon produced by diatom biofilms during tidal exposure (Staats et al. 2000, de Brouwer \& Stal 2001, Perkins et al. 2001, Hanlon et al. 2006) is present within the LMW fraction.
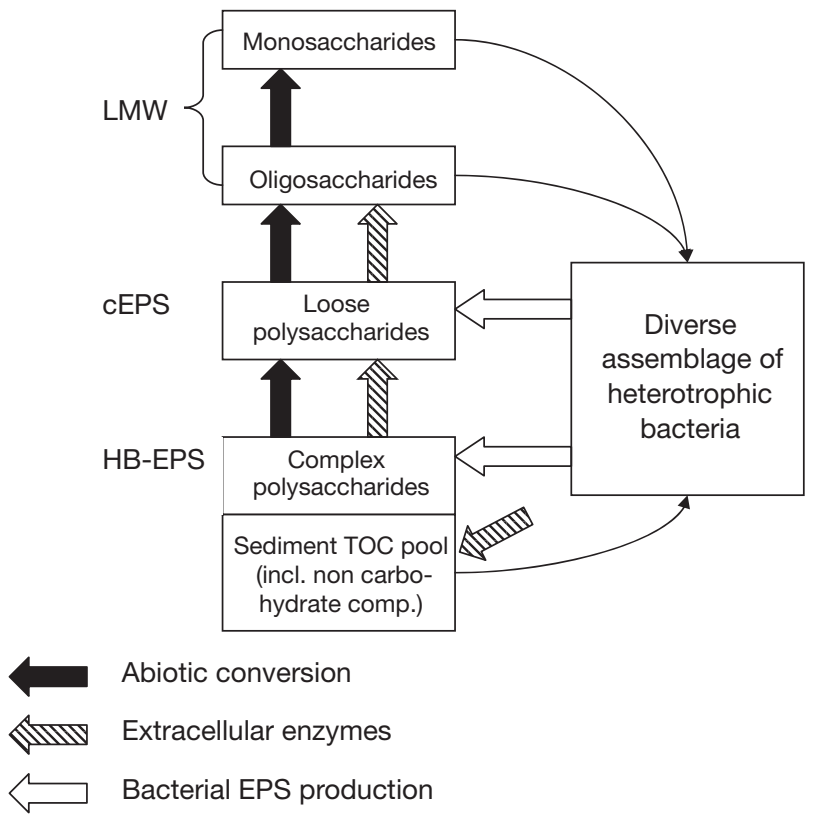

Abiotic conversion

\section{Extracellular enzymes \\ Bacterial EPS production}

Fig. 5. Conceptual model of carbohydrate breakdown in estuarine sediments, showing routes of abiotic and biotic transformation of material and update into heterotrophic bacteria, and the provenance of the 3 operational carbohydrate fractions used in the present study . LMW: low molecular weight; for other abbreviations see Table 1 
${ }^{14} \mathrm{C}$ tracer studies have shown rapid utilisation of such material produced by mixed benthic algae and 2 species of diatoms occurring within $2 \mathrm{~h}$ of addition (Goto et al. 2001). However, in both the control and colloidal carbohydrate enrichments in Expt 1, there were significant increases in LMW carbohydrate concentrations in the first 2 to $4 \mathrm{~h}$, followed by a reduction later in the incubation. Such increases would be consistent with the idea that both abiotic and biotic (bacterial) breakdown of EPS molecules occurs (Fig. 5), liberating smaller molecular-sized fractions (Haynes et al. 2007). Physical mixing of the slurries may have caused liberation of material from the complex pool of detrital organic carbon due to mechanical disruption of polymers, or via chemical hydrolysis of polysaccharides present in the sediments. In addition, extracellular hydrolysing enzymes already present in sediments can continue to liberate smaller sugar units, even if 'new' microbial action is inhibited (Hanlon et al. 2006). Changes in the poisoned colloidal enrichment treatment suggest that a degree of abiotic release did take place, but these were much less than changes in concentrations in the non-poisoned treatments. Thus, under these slurry conditions used in the present study, the major changes in the concentrations of carbohydrate fractions in sediment slurries would appear to be predominantly due to heterotrophic action (Haynes et al. 2007).

\section{Utilisation of EPS}

There were significant reductions in the concentrations of cEPS only in the cEPS-enriched treatment, where starting concentrations of cEPS were much higher than those of LMW carbohydrate. In this treatment, though the enrichment was substantial $(+2200 \%)$, the concentrations of cEPS at the beginning of the experiment were well within the range measured in natural diatom-dominated estuarine biofilms (Underwood \& Smith 1998, de Brouwer et al. 2003, Bellinger et al. 2005). In the cEPS enrichments (Fig. 1d), there was no initial increase in LMW carbohydrate, suggesting that at these higher starting concentrations of cEPS, overall heterotrophic activity was stimulated, resulting in the simultaneous utilisation of both cEPS and any LMW carbohydrate produced by degradation of EPS. However, the increases in cEPS concentrations in the control (Fig. 1a), and lack of significant changes in cEPS concentrations in the colloidal enrichments (Fig. 1b), do not mean that EPS was not being degraded by heterotrophic action in those treatments. The sediments contain a substantial pool of carbohydrate material, of which cEPS is only a fraction (between 5 and 20\%, Underwood \& Paterson 1993,
Bellinger et al. 2005). Utilisation of cEPS could be matched by breakdown of more refractory carbohydrates (Veuger et al. 2007) resulting in new products that would be present in the EPS extraction (Fig. 5). Evidence supporting this idea comes from the changes in monosaccharide composition of the EPS. Particularly in the controls, but also in the colloidal enrichments, the cEPS fractions at the beginning of the experiment were rich in glucose and galactose. The proportion of glucose fell significantly in the controls and colloidal enrichments, indicating preferential removal of glucose from the system (de Brouwer \& Stal 2001) and the production of new cEPS with a monosaccharide profile similar to that found in more refractory sediment carbohydrate components (de Brouwer \& Stal 2001, Bellinger et al. 2005). The amount of glucose present in the control slurries (Fig. 2a) was high $(\approx 70 \%)$, but similar to values measured in natural sediments (Taylor et al. 1999, de Brouwer \& Stal 2001, Bellinger et al. 2005). Glucose content in natural biofilms increases during the period of tidal exposure as cells photosynthesize, and decreases during tidal cover (de Brouwer \& Stal 2001, Hanlon et al. 2006). Selective loss of glucose during degradation of EPS has been recorded in lake phytoplankton (Giroldo et al. 2003). Some of the glucose present in the EPS samples may have originated from intracellular glucan (chrysolaminaran), which is the main storage carbohydrate of diatoms. However, all the cEPS samples were obtained by alcohol precipitation of colloidal supernatant, and diatom glucan does not precipitate in cold ethanol (de Brouwer \& Stal 2004). However, during precipitation, smaller oligosaccharides and monosaccharides can be trapped in the gel matrix formed, so the high levels of glucose in the cEPS of control samples might be partly a result of LMW contamination of the smaller quantities of EPS present. Where the cEPS content of the slurries was increased by enrichment with isolated and partly purified EPS, the glucose content was lower and showed less marked temporal decreases. With high initial concentrations of cEPS (cEPS enrichments, Fig. 1d), there was no major change in the monosaccharide profile, despite reductions in concentration, suggesting that any new cEPS released from more refractory pools had a similar monosaccharide profile to the material that had been removed.

Similarities in the EPS composition of cEPS and hotbicarbonate extractable EPS, and the correlation between extracellular enzyme activity and changing carbohydrate concentrations in sediments, suggest that cEPS can be produced from the breakdown of HB-carbohydrates (Hanlon et al. 2006, Haynes et al. 2007, Bellinger et al. unpubl. data) and other more structural EPS components, e.g. EDTA-extracted EPS (de Brouwer \& Stal 2001). 
A second process that could explain increasing EPS concentrations and changing monosaccharide content in the slurries would be changes in the quantity or the solubility of bacterial EPS present in the sediment. Very little is known about the contribution of bacterial EPS to the EPS pool of intertidal biofilms, despite the high bacterial cell numbers in such sediments (Underwood \& Paterson 1993, van Oevelen et al. 2006a) and a clear spatial association between bacterial cells and EPS in artificial estuarine biofilms (Mueller et al. 2006). Bacteria have been found to contribute significantly to river sediment carbohydrate content (Gerbersdorf et al. 2008), and bacterial cell numbers are correlated with the total sediment carbohydrate content (Underwood \& Paterson 1993). Most prior investigation of the EPS pool in intertidal sediments has concentrated on the pathways of MPB autotrophic production of carbohydrates (Underwood \& Paterson 2003), and the bacterial contribution to sediment EPS dynamics is largely undescribed.

\section{Bacterial growth on different EPS}

The EPS-degrading bacterial isolate obtained by enrichment culture of estuarine sediments was identified as a member of the genus Variovorax, belonging to the $\beta$-proteobacteria. The $\beta$-proteobacteria are important constituents of the bacterial community in freshwater systems, with a lower relative abundance (compared to $\alpha$ - and $\gamma$-proteobacteria) in estuarine and marine habitats (Simon et al. 2002). Hanlon et al. (2006) showed that it is not necessarily the most abundant bacteria that respond to changes in sediment EPS concentrations. Variovorax species are found in soils and in freshwater biofilm environments (Rickard et al. 2003), where they are able to degrade complex organic compounds and also form mutually beneficial consortia with other bacteria (Dejonghe et al. 2003). Variovorax sp. Arl1 was able to grow on cEPS, and also produced substantial quantities of new EPS rich in galactose, fucose and rhamnose. During the early stages of the bacterial culture experiments, the glucose content of the cEPS in the cultures decreased (similar to the pattern found in Expt 1 control slurries), suggesting glucose was being utilised. In the first $24 \mathrm{~h}$ of growth, there was little extracellular $\beta$-glucosidase activity in the cultures with cEPS as a carbon source. Increased extracellular enzyme activity is usually associated with a reduction in concentrations of easily assailable carbon sources and increased utilisation of structural polysaccharides as a carbon source (Boetius \& Lochte 1996). After $24 \mathrm{~h}$, the bacteria were utilising more refractory carbohydrate sources, synthesising $\beta$ glucosidase and producing a new EPS, with a different profile to the starting conditions (Fig. 4b). The total organic content of the cEPS carbon source used in these experiments were not measured (cEPS extracts also contain non-carbohydrate components of the polymeric molecules), but there was clearly an additional $\mathrm{C}$ source present to allow for the increases in total (including bacterial cells) and extracellular carbohydrates over time. This could be protein, or structural polysaccharides that were not fully hydrolysed by the phenol-sulphuric acid assay (and were therefore underestimated when compared against a glucose standard) but that were still available to the bacteria.

Variovorax sp. Arl1 showed no net growth upon enrichment with the HB-extracted EPS. Though the HB-extracted EPS used as a carbon source was similar in monosaccharide composition to EPS in the cEPS enrichments in Expt 1, similarity in the monosaccharide profile does not necessarily imply that the linkage patterns were similar. Therefore, HB-EPS could have quite a different tertiary structure from that of cEPS, which would affect the ability of enzymes to cleave these molecules. Ideally, linkage analysis would have been done on all the EPS extractions in the present study, but these analyses require substantial quantities of purified material, which this experimental design could not provide. HB-extracted EPS are tightly bound polymers, contributing to structures such as stalks and tubes of some marine diatoms (Wustman et al. 1997). This HB-EPS persists in the environment, demonstrating much less temporal variability in concentration or composition over diel time scales in situ compared to LMW carbohydrate or cEPS (Hanlon et al. 2006, Bellinger et al. unpubl. data). The evidence of a significant correlation between HB-extracted carbohydrate concentration and $\beta$-glucosidase activity from indigenous bacteria present in natural sediment slurries (Haynes et al. 2007) would suggest that HB-extracted carbohydrate is a more refractory carbon source than cEPS. Our data indicate that despite evidence of production of extracellular enzymes (Fig. 4b), Variovorax sp. Arl1 could not utilise HB-EPS within 72 h, despite similarity in monosaccharide composition between HB-EPS and cEPS. Tertiary structure is probably an additional factor that determines whether a bacterial strain isolated for its ability to grow on cEPS can grow easily on HB-EPS. Structural polysaccharides in sediment break down slowly; Veuger et al. (2006) showed that peptidoglycan can take up to $100 \mathrm{~d}$ to be degraded. Knowing the monosaccharide composition of these structural fractions is a useful component in our understanding of the carbon cycling pathways in sediments, but further detailed studies of the changing molecular structure of these compounds during degradation, and the degree of substrate-specificity in mixed sediment bacteria assemblages are needed. 


\section{Conclusions}

The degradation of EPS in estuarine sediments is a multi-step process. The sediment carbohydrate pool represents a continuum from highly refractory, detrital material, through a range of structured (i.e. tubes, pads) and less structured EPS (i.e. loose mucilage) to LMW carbohydrate. It is important to recognise that the extraction techniques generally used remove certain proportions of this continuum, and that certain discrete groups of carbohydrates (and other constituents) may be found in one extraction but not in another. The LMW fraction is rapidly utilised, but degradation of polymeric material can generate new LMW material. Freshly extracted diatom EPS may have a high glucose content, but degradation of these molecules by heterotrophs, as well as subsequent production of new EPS, can result in an altered monosaccharide composition of the cEPS fraction with time, even if the concentration of EPS does not change. The fluxes of carbon through these different carbohydrate pools can be rapid from hours to days (Smith \& Underwood 1998, Hanlon et al. 2006) with different bacterial groups utilising the carbon selectively (Bellinger et al. 2009). Models of bacterial activity in sediments (e.g. van Oevelen et al. 2006b) have considered 2 pools: labile dissolved organic carbon (DOC) and less reactive particulate organic carbon (POC). In the absence of more comprehensive data, this is a necessary simplification, but the data presented here support the idea that the sediment DOC pool contains a range of components; for example, different groups of EPS of varying levels of bioavailability and of various origins (e.g. bacterial, algal). Understanding the turnover times of the different components of sediment carbohydrate in MPB biofilms is important. Inputs of carbon-rich EPS into the sediment food web substantially increases the $\mathrm{C}: \mathrm{N}$ ratio of the organic pool, which, in turn, creates increased competition between bacteria, and between bacteria and MPB, for nitrogen (Cook et al. 2004, 2007). Such interactions can affect sedimentwater $\mathrm{N}$ fluxes and rates of nitrification and denitrification in mudflats (Risgaard-Petersen 2003), which can have consequences for nutrient cycling in estuarine ecosystems (Thornton et al. 2007).

Acknowledgements. This work was funded by a grant awarded to G.J.C.U., A.S.B. and A.M.O. from the UK Natural Environment Research Council (ref. NER/A/S/2001/00536), and a NERC PhD studentship award to J.D.T. We gratefully acknowledge M. R. Gretz, Michigan Technological University, Houghton, USA, for his advice relating to monosaccharide analysis, and the constructive comments of 3 anonymous reviewers.

\section{LITERATURE CITED}

Abdullahi AS, Underwood GJC, Gretz MR (2006) Extracellular matrix assembly in diatoms (Bacillariophyceae). V. Environmental effects on polysaccharide synthesis in the model diatom, Phaeodactylum tricornutum. J Phycol 42: 363-378

Bellinger BJ, Abdullahi AS, Gretz MR, Underwood GJC (2005) Biofilm polymers: relationship between carbohydrate biopolymers from estuarine mudflats and unialgal cultures of benthic diatoms. Aquat Microb Ecol 38: 169-180

Bellinger BJ, Underwood GJC, Ziegler SE, Gretz MR (2009) Significance of diatom-derived polymers in carbon flow dynamics within estuarine biofilms determined through isotopic enrichment. Aquat Microb Ecol 55: in press

Bhaskar PV, Bhosle NB (2005) Microbial extracellular polymeric substances in marine biogeochemical processes. Curr Sci 88:45-53

> Bhinu VS (2005) Insight into biofilm-associated microbial life. J Mol Microbiol Biotechnol 10:15-21

Boetius A, Lochte K (1996) Effect of organic enrichments on hydrolytic potentials and growth of bacteria in deep-sea sediments. Mar Ecol Prog Ser 140:239-250

Chiovitti A, Molino P, Crawford SA, Teng R, Spurck T, Wetherbee R (2004) The glucans extracted with warm water from diatoms are mainly derived from intracellular chrysolaminaran and not extracellular polysaccharides. Eur J Phycol 39:117-128

Cook PLM, Revill AT, Clementson LA, Volkman JK (2004) Carbon and nitrogen cycling on intertidal mudflats of a temperate Australian estuary. II. Nitrogen cycling. Mar Ecol Prog Ser 280:39-54

> Cook PLM, Veuger B, Böer S, Middelburg JJ (2007) Effect of nutrient availability on carbon and nitrogen incorporation and flows through benthic algae and bacteria in nearshore sandy sediment. Aquat Microb Ecol 49:165-180

de Brouwer JFC, Stal LJ (2001) Short-term dynamics in microphytobenthos distribution and associated extracellular carbohydrates in surface sediments of an intertidal mudflat. Mar Ecol Prog Ser 218:33-44

de Brouwer JFC, Stal LJ (2004) Does warm water extraction of benthic diatoms yield extracellular polymeric substances or does it extract intracellular chrysolaminaran? Eur J Phycol 39:129-131

de Brouwer JFC, Wolfstein K, Stal LJ (2002) Physical characterisation and diel dynamics of different fractions of extracellular polysaccharides in an axenic culture of a benthic diatom. Eur J Phycol 37:37-44

de Brouwer JFC, de Deckere EMGT, Stal LJ (2003) Distribution of extracellular carbohydrates in three intertidal mudflats in Western Europe. Estuar Coast Shelf Sci 56: 313-324

Decho AW (1990) Microbial exopolymer secretions in ocean environments: their role(s) in food webs and marine processes. Oceanogr Mar Biol Annu Rev 28:73-153

> Dejonghe W, Berteloot E, Goris J, Boon N and others (2003) Synergistic degradation of linuron by a bacterial consortium and isolation of a single linuron-degrading Variovorax strain. Appl Environ Microbiol 69:1532-1541

> Dubois M, Gilles KA, Hamilton JK, Rebers PA, Smith F (1956) Colorimetric method for determination of sugars and related substances. Anal Chem 28:350-356

> Gerbersdorf SU, Jancke T, Westrich B, Paterson DM (2008) Microbial stabilisation of riverine sediments by extracellular polymeric substances. Geobiology 6:57-69

Giroldo D, Vieira AAH, Paulsen BS (2003) Relative increase of 
deoxy sugars during microbial degradation of an extracellular polysaccharide released by a tropical freshwater Thalassiosira sp. (Bacillariophyceae). J Phycol 39: 1109-1115

Goto N, Kawamura T, Mitamura O, Terai H (1999) Importance of extracellular organic carbon production in the total primary production by tidal-flat diatoms in comparison to phytoplankton. Mar Ecol Prog Ser 190:289-295

Goto N, Mitamura O, Terai H (2001) Biodegradation of photosynthetically produced extracellular organic carbon from intertidal benthic algae. J Exp Mar Biol Ecol 257:73-86

Hanlon ARM, Bellinger B, Haynes $\mathrm{K}$, Xiao G and others (2006) Dynamics of extracellular polymeric substance (EPS) production and loss in an estuarine, diatom-dominated, microalgal biofilm over a tidal emersion-immersion period. Limnol Oceanogr 51:179-193

Haynes K, Hofmann TA, Smith CJ, Ball AS, Underwood GJC, Osborn AM (2007) Diatom-derived carbohydrates as factors affecting bacterial community composition in estuarine sediments. Appl Environ Microbiol 73:6112-6124

> Higgins MJ, Molino P, Mulvaney P, Wetherbee R (2003) The structure and nanomechanical properties of the adhesive mucilage that mediates diatom-substratum adhesion and motility. J Phycol 39:1181-1193

Hoagland KD, Rosowski JR, Gretz MR, Roemer SC (1993) Diatom extracellular polymeric substances: function, fine structure, chemistry and physiology. J Phycol 29:537-566

Hoppe HG (1983) Significance of exoenzymatic activities in the ecology of brackish water: measurements by means of methylumbelliferyl-substrates. Mar Ecol Prog Ser 11: 299-308

Kisand V, Cuadros R, Wikner J (2002) Phylogeny of culturable estuarine bacteria catabolizing riverine organic matter in the Northern Baltic Sea. Appl Environ Microbiol 68: 379-388

Middelburg JJ, Barranguet C, Boschker HTS, Herman PMJ, Moens T, Heip CHR (2000) The fate of intertidal microphytobenthos carbon: an in situ ${ }^{13} \mathrm{C}$-labelling study. Limnol Oceanogr 45:1224-1234

Miller JH (1972) Experiments in molecular genetics. Cold Spring Harbor Laboratory Press, Cold Spring Harbor, NY

Mueller LN, de Brouwer JFC, Almeida JS, Stal LJ, Xavier JB (2006) Analysis of a marine phototrophic biofilm by confocal laser scanning microscopy using the new image quantification software PHLIP. BMC Ecol 6:1 doi:10.1186/ 1472-6785-6-1

> Orvain F, Galois R, Barnard C, Sylvestre A, Blanchard G, Sauriau PG (2003) Carbohydrate production in relation to microphytobenthic biofilm development: an integrated approach in a tidal mesocosm. Microb Ecol 45:237-251

Osborn AM, Bruce KD, Ritchie DA, Strike P (1993) PCR-RFLP analysis shows divergence among mer determinants from Gram-negative bacteria indistinguishable by DNA-DNA hybridisation. Appl Environ Microbiol 59:4024-4030

Perkins RG, Underwood GJC, Brotas V, Snow G, Jesus B, Ribeiro L (2001) Responses of microphytobenthos to light: primary production and carbohydrate allocation over an emersion period. Mar Ecol Prog Ser 223:101-112

Pinckney J, Zingmark RG (1991) Effects of tidal stage and sun angles on intertidal benthic microalgal productivity. Mar Ecol Prog Ser 76:81-89

Priest FG (1992) Synthesis and secretion of extracellular enzymes in bacteria. In: Winkelmann G (ed) Microbial degradation of natural products. VCH Publishing, Weinheim, $\mathrm{p}$ 1-26

Rickard AH, McBain AJ, Ledder RG, Handley PS, Gilbert P (2003) Coaggregation between freshwater bacteria within biofilm and planktonic communities. FEMS Microbiol Lett 220:133-140

Risgaard-Petersen N (2003) Coupled nitrification-denitrification in autotrophic and heterotrophic estuarine sediments: on the influence of benthic microalgae. Limnol Oceanogr 48:93-105

Selje N, Brinkhoff T, Simon M (2005) Detection of abundant bacteria in the Weser estuary by culture-dependent and culture-independent approaches. Aquat Microb Ecol 39: $17-34$

> Simon M, Grossart HP, Schweitzer B, Ploug H (2002) Microbial ecology of organic aggregates in aquatic ecosystems. Aquat Microb Ecol 28:175-211

Smith DJ, Underwood GJC (1998) Exopolymer production by intertidal epipelic diatoms. Limnol Oceanogr 43: $1578-1591$

Staats N, de Winder B, Stal LJ, Mur LR (1999) Isolation and characterisation of extracellular polysaccharides from the epipelic diatoms Cylindrotheca closterium and Navicula salinarum. Eur J Phycol 34:161-169

Staats N, Stal LJ, de Winder B, Mur LR (2000) Oxygenic photosynthesis as driving process in exopolysaccharide production of benthic diatoms. Mar Ecol Prog Ser 193: 261-269

Stal LJ (2003) Microphytobenthos, their extracellular polymeric substances, and the morphogenesis of intertidal sediments. Geomicrobiol J 20:463-478

Stevens H, Stübner M, Simon M, Brinkhoff T (2005) Phylogeny of Proteobacteria and Bacteroidetes from oxic habitats of a tidal flat ecosystem. FEMS Microbiol Ecol 54: 351-365

Taylor IS, Paterson DM, Mehlert A (1999) The quantitative variability and monosaccharide composition of sediment carbohydrates associated with intertidal diatom assemblages. Biogeochemistry 45:303-327

Thornton DCO, Dong LF, Underwood GJC, Nedwell DB (2002) Factors affecting microphytobenthic biomass, species composition and production in the Colne estuary (UK). Aquat Microb Ecol 27:285-300

Thornton DCO, Dong LF, Underwood GJC, Nedwell DB (2007) Sediment-water inorganic nutrient exchange and nitrogen budgets in the Colne estuary, UK. Mar Ecol Prog Ser 337:63-77

Underwood GJC (2002) Adaptations of tropical marine microphytobenthic assemblages along a gradient of light and nutrient availability in Suva Lagoon, Fiji. Eur J Phycol 37 : $449-462$

Underwood GJC, Paterson DM (1993) Seasonal changes in diatom biomass, sediment stability and biogenic stabilization in the Severn Estuary. J Mar Biol Assoc UK 73: 871-887

Underwood GJC, Paterson DM (2003) The importance of extracellular carbohydrate production by marine epipelic diatoms. Adv Bot Res 40:183-240

Underwood GJC, Smith DJ (1998) Predicting epipelic diatom exopolymer concentrations in intertidal sediments from sediment chl a. Microb Ecol 35:116-125

Underwood GJC, Paterson DM, Parkes RJ (1995) The measurement of microbial carbohydrate exoploymers from intertidal sediments. Limnol Oceanogr 40:1243-1253

Underwood GJC, Perkins RG, Consalvey MC, Hanlon ARM, Oxborough K, Baker NR, Paterson DM (2005) Patterns in microphytobenthic primary productivity: species-specific variation in migratory rhythms and photosynthetic efficiency in mixed-species biofilms. Limnol Oceanogr 50: 755-767

van Duyl FC, de Winder B, Kop AJ, Wollenzien U (1999) Tidal 
coupling between carbohydrate concentrations and bacterial activities in diatom-inhabited intertidal mudflats. Mar Ecol Prog Ser 191:19-32

van Duyl FC, de Winder B, Kop AJ, Wollenzien U (2000) Consequences of diatom mat erosion for carbohydrate concentrations and heterotrophic bacterial activities in intertidal sediments of the Ems-Dollard estuary. Cont Shelf Res 20: 1335-1349

van Oevelen D, Moodley L, Soetaert K, Middelburg JJ (2006a) The trophic significance of bacterial carbon in a marine intertidal sediment: results of an in situ stable isotope labeling study. Limnol Oceanogr 51:2349-2359

van Oevelen D, Middelburg JJ, Soetaert K, Moodley L (2006b) The fate of bacterial carbon in an intertidal sediment: modeling an in situ isotope tracer experiment. Limnol Oceanogr 51:1302-1314

Vetter YA, Deming JW, Jumars PA, Krieger-Brockett BB

Editorial responsibility: Rodney Forster,

Lowestoft, UK
(1998) A predictive model of bacterial foraging by means of freely released extracellular enzymes. Microb Ecol 36: $75-92$

Veuger B, van Oevelen D, Boschker HTS, Middelburg JJ (2006) Fate of peptidoglycan in an intertidal sediment: an in situ ${ }^{13} \mathrm{C}$-labeling study. Limnol Oceanogr 51: $1572-1580$

Veuger B, Eyre BD, Maher D, Middelburg JJ (2007) Nitrogen incorporation and retention by bacteria, algae and fauna in a subtropical intertidal sediment: an in situ ${ }^{15} \mathrm{~N}$-labeling study. Limnol Oceanogr 52:1930-1942

- Wustman BA, Gretz MR, Hoagland KD (1997) Extracellular matrix assembly in diatoms (Bacillariophyceae). I. A model of adhesives based on chemical characterisation and localisation of polysaccharides from the marine diatom Achnanthes longipes and other diatoms. Plant Physiol 113: 1059-106

Submitted: August 1, 2008; Accepted: December 3, 2008 Proofs received from author(s): March 3, 2009 